\section{THE EFFECT OF TAPIOCA-BASED EDIBLE COATING ENRICHED WITH NISIN ON QUALITY OF PATIN (PANGASIUS HYPOPHTHALMUS) FILLET DURING COLD STORAGE}

\author{
Rohula Utami*, Asri Nursiwi, Nadia Wohon
}

Department of Food Science and Technology, Faculty of Agriculture, Universitas Sebelas Maret, Ir. Sutami 36A Kentingan, Surakarta - 57126, Indonesia
Article history

Received

4 October 2017

Received in revised form

8 February 2018

Accepted

15 February 2018

Published online

3 June 2018

*Corresponding author rohulautami@staff.uns.ac.id

\section{Graphical abstract}

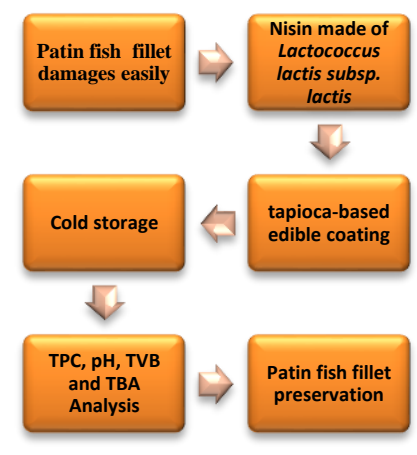

\begin{abstract}
The effect of tapioca-based edible coating enriched with nisin in preserving the quality of patin fish fillet during cold stored $(410 \mathrm{C})$ for 16 days was evaluated. The examination was conducted including Total Plate Count (TPC), pH, TVB (Total Volatile Base), and TBA (Thiobarbituric Acid) values. The results showed that the tapioca-based edible coating enriched with nisin significantly has affected the TPC, TVB, and TBA values, and insignificantly affected the $\mathrm{pH}$ of patin fillets samples. The higher nisin activity on the tapioca-based edible coating solutions, the better effect on maintaining the quality of patin fish fillets. Enrichment of nisin at $2000 \mathrm{lU} / \mathrm{ml}$ on tapioca-based edible coating solution could maintain the patin fish fillets quality during 16 th day stored at $410 \mathrm{C}$.
\end{abstract}

Keywords: Nisin, edible coating, tapioca, patin, fillet

\subsection{INTRODUCTION}

Patin fish (Pangasius hypophthalmus) is a freshwater fish found widely in Indonesian fresh water and has been cultivated due to high export potency. According to Cultivation Directorate General of Indonesian Marine and Fishery Ministry's Annual Report [1], patin fish production from 2010 to 2013 has increased $95.57 \%$, and in 2013 , patin fish production has increased dramatically to 972,778 tons. As an export commodity, patin fish fillet is more profitable because it is processed easily and has higher selling price [2]. However, fish fillet is easily spoiled due to degrading enzyme activity, oxidation, and microbial activity.

Refrigeration is one of the methods to inhibit the spoilage of fish fillet. However, fish fillet stored at cold temperature in a long time has not been able completely to inhibit the spoilage due to microbial growth and chemical reaction. The shelf life of fish fillets stored between $10-0^{\circ} \mathrm{C}$ were 2-5 days [3]. Refrigeration may be combined with other preservation methods to extend the shelf life of fish fillets such as the application of bio-preservative.

Nisin is known as bacteriocin constituting biopreservative released by Lactococcus lactis subs. Lact is used commercially in food product [4]. Nisin has been verified as a GRAS (Generally recognized as safe) substance by World's Food Association Organization/WHO) as natural preservative and nisin also is one of 25 food additive substances permitted in Indonesia [5]. Nisin has been reported effective against gram positive pathogens and inhibits the growth of Clostridium and Bacillus spores. Nisin as food preservative has been used many products such as cheese, and canned food [6].

For fishery products, nisin spray $(100 \mu \mathrm{g} / \mathrm{g})$ on rainbow trout showed to improve the fish quality and 
extend the shelf life of the fish from 12 to 16 days at 4 ${ }^{\circ} \mathrm{C}$ [7]. Spraying nisin (2000 IU/ml) on patin fillet also could extend the shelf-life of fillet until 12th days during refrigerated storage $\left(4 \pm 1^{\circ} \mathrm{C}\right)$ [8]. However, a direct technique for bio-preservatives application on food surfaces such as by spraying has limited benefits due to the rapid loss of antimicrobial activity of biopreservatives [9]. Slow release of the antimicrobials provides by the application of edible film [10].

Edible films containing nisin have been developed from various materials such as hydroxypropylmethylcellulose [11], whey protein isolate [12,13], soy protein isolate, egg albumin, wheat gluten [13], sodium caseinate [14], calcium alginate [15], bacterial cellulose [16], and tapioca starch $[17,10]$ and proved could inhibit the growth of undesirable microorganisms. Bacterial cellulose films containing nisin significantly reduced the growth of $L$. monocytogenes and total aerobic plate counts on Frankfurter [16]. Sodium caseinate films containing nisin (1000IU/cm2) retarded $L$. innocua growth in the surface of the cheese and extended the shelf life [18]. Tapioca edible film combined with nisin also can control L. innocua growth on Port Salute cheese [9].

Tapioca starch-based edible coating enriched with red ginger, red galangal [19], kaempferia rotunda and Curcuma xanthorrhiza essential oil [20] have been reported could maintain the quality of patin fillet during refrigeration storage and frozen storage $[21,22]$. However, the application of tapioca starch-based edible coating enriched with nisin on patin fish fillet has not been reported. Therefore, this study aimed to investigate the effect of tapioca starch-edible coating enriched with nisin on the quality of patin fish fillet during cold storage.

\subsection{METHODOLOGY}

\subsection{Patin Fish Fillet Preparation}

Patin fish (approximately 300-500 g) was obtained from Lembah Hijau Multifarm (Sukoharjo, Indonesia). The fish were beheaded, gutted, filleted, skinned and cleaned to obtain fish fillet. The cleaned fish fillets were stored in ziplock plastic (PP $0.08 \mathrm{~mm}$ ) and placed into coolbox until nisin was applied to the fish fillet.

\subsection{Edible Coating Solution Preparation}

The edible coating was made of tapioca starch using glycerol from Merck as plasticizer serving to deal with film fragility and to improve flexibility. The preparation of edible solution with a variety of nisin activity was conducted using modified method [23]. 1 g nisin powder with 1,000,000 IU/g activity (Sigma-Aldrich Pte Ltd.) was solved in $\mathrm{HCl} 0.02 \mathrm{~N}$ up to $100 \mathrm{ml}$ so that the solution activity of $10,000 \mathrm{lU} / \mathrm{ml}$ was obtained. The solution containing $12.5 \mathrm{~g}$ tapioca flour and $5 \mathrm{mg}$ glycerol was dissolved into $250 \mathrm{ml}$ aquades and heated at $68-70^{\circ} \mathrm{C}$ for 30 minutes. Nisin solution in varying volumes: 12.5; 25; and $50 \mathrm{ml}$ was put into 250 $\mathrm{ml}$ edible solution and stirred using stirrer, so that nisin activity was obtained in edible solution of $500 \mathrm{lU} / \mathrm{ml}$ (0,5 mg nisin/ml), $1000 \mathrm{lU} / \mathrm{ml}$ (1 mg nisin/ml), and 2000 $\mathrm{IU} / \mathrm{ml}$ (2 mg nisin/ml).

\subsection{Coating Treatments}

Patin fish fillet was immersed into edible coating solution and dried on dryer box for 45 minutes. Each fillet sample was placed at styrofoam plate and wrapped with wrapping plastic. The packed fillet was stored in the refrigerator at $4 \pm 1^{\circ} \mathrm{C}$. The quality of patin fish fillet was analyzed on the day $0,4,8,12$, and 16 of storage. Total Plate Count (TPC) analysis was used to enumerate the number of microbes expressed in log CFU/g and analyzed based on Indonesian National Standard 2332.2: 2015 [24]. The measurement of $\mathrm{pH}$ was conducted to find out the decomposition level of fish meat measured using $\mathrm{pH}$ meter (Hanna Instrument) [25]. Total Volatile Base (TVB) represented protein damage and was analyzed using Conwaymicro diffusion method based on Indonesian National Standard 2354.8:2009 [26]. Thiobarbituric Acid (TBA) value showed lipid oxidation of fish meat expressed in mg malonaldehyde per $\mathrm{kg}$ (mg MA/kg) [27].

\subsection{Statistical Analysis}

The experimental design used in this research was Completely Random Design (CRD) with one factor, varying nisin activities were added: 0, 500, 1000, 2000 $\mathrm{IU} / \mathrm{ml}$. Individual treatment was replicated twice. The data analysis was performed using One Way ANOVA (SPSS, version 19) and continued with Duncan's Multiple Range Test (DMRT) at the significance level of $a=5 \%$.

\subsection{RESULTS AND DISCUSSION}

\subsection{Total Plate Count}

The change in total microbes in fish fillet stored at $4 \pm 1^{\circ} \mathrm{C}$ for 16 day storage is shown in Figure 1. The initial TPC value ranged from 3.9 - $4.3 \mathrm{log}$ CFU/g. During storage, the TPC value in each of patin fish fillets with varying nisin activity treatments increased as the storage time increases. Based on SNI 7388:2009 [28], the maximum threshold of microorganisms contamination in frozen fresh fish fillet was $5 \times 10^{5}$ CFU/g (5.7 log CFU/g). After four day storage, the TPC value of $0 \mathrm{IU} / \mathrm{ml}$ (control) sample has achieved $6.2 \mathrm{log}$ CFU/g that exceeded the maximum threshold. The patin fish fillet with the activity of $500 \mathrm{IU} / \mathrm{ml}$ has exceeded the maximum threshold in fresh fish fillet on the day-8 (6.7 log/CFU/g). 


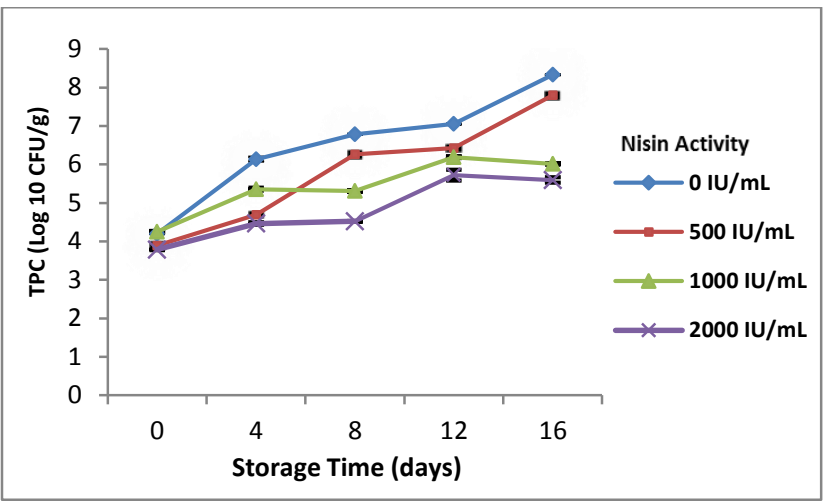

Figure 1 The Effect of Edible Coating Enriched with Nisin on Total Plate Count (TPC) of Patin Fish Fillet During Cold Storage at $4 \pm 1^{\circ} \mathrm{C}$

Fish fillet stored at 10 to $0^{\circ} \mathrm{C}$ has shelf life $2-5$ days [5]. In the presence of nisin as preservatives, the shelf life of patin fish fillet can be extended. The treatment with nisin activity of $1000 \mathrm{IU} / \mathrm{ml}$ can maintain fish fillet freshness stored at $4 \pm 1^{\circ} \mathrm{C}$ up to day-8 and the treatment with nisin activity of $2000 \mathrm{IU} / \mathrm{ml}$ can maintain the fish fillet freshness longer up to the day16. It indicates that the nisin activity of $1000 \mathrm{lU} / \mathrm{ml}$ and $2000 \mathrm{IU} / \mathrm{ml}$ is an optimal activity to inhibit microbe in patin fish fillet because it can maintain the fish freshness up to more than five days. The higher the nisin activity used, the higher the microbial growth inhibiting effect. Antimicrobial activity of bacteriocin can be bactericidal (killing bacteria) and bacteriostatic (inhibiting bacterial growth) dependent on nisin concentration added, the bacterial number in food material and other supporting factors such as $\mathrm{pH}$, temperature, Aw [4, 29].

Fish contains resident flora number existing on the skin surface, gill, and digestion track [30]. When the fish is alive, bacteria existing in its body do not result in decomposition process because it still has a natural defense system, but when it dies, bacteria start to attack tissue and distribute to the fish body so that the longer the storage time, the higher is the microbial activity. The type of early microflora generally contained in fresh patin fish consists of gram positive bacteria including Micrococcus, Staphylococcus, Streptococcus, Bacillus alvei. Meanwhile, the gram negative bacteria species includes Aeromonas, Acinetobacter, Enterobacter, Pseudomonas, Vibrio and Flavobacterium [31]. In the observation on the last day, day-16, patin fish fillet with the activity of 0 $\mathrm{IU} / \mathrm{ml}$ shows the highest TPC value of $8.3 \mathrm{log}$ CFU/g and the lowest one found in the patin fish fillet with the activity of $2000 \mathrm{IU} / \mathrm{ml}$. The result of ANOVA SPSS at the significance level of $a=0.05$ shows that the nisin activity affected the TPC value of patin fish fillet.

Previous studies reported that the total microbes in rainbow trout fish that sprayed with $100 \mu \mathrm{g} / \mathrm{g}$ nisin and stored in vacuum packaging still below 6 log CFU/g after cold storage for 16 days [7]. Those studies indicated that antibacterial activity of nisin could inhibit bacteria growth in rainbow trout fish stored at $4^{\circ} \mathrm{C}$ up to the day-16. Some other studies reported that the use of $150.000 \mathrm{IU} / \mathrm{kg}$ nisin in rainbow trout fish fillet stored in vacuum package indicated total microbes more than log 7 CFU/g after having been stored at $4^{\circ} \mathrm{C}$ for 15 days [32].

Generally, bacteriocin has an ability of resisting other bacteria with bactericidal effect in the following mechanism: (a) bacteriocin molecule contacts the cellular membrane, (b) this contact process disturbs potential cytoplasm membrane in the form of destabilization so that cellular becomes weak, and (c) cellular membrane instability creates holes/pores on the membrane by harming PMF. The creation of holes on cytoplasm due to the presence of bacteriocin results in the changing gradient potential membrane (DP) and releases intracellular substance (from the environment). As a result, cellular growth is inhibited, and the cells sensitive to bacteriocin die [29].

\section{$3.2 \mathrm{pH}$ Value}

$\mathrm{PH}$ value with varying nisin activities is presented in Figure 2. The initial $\mathrm{pH}$ value of samples was at the neutral range, and after storage at $4 \pm 1^{\circ} \mathrm{C}$ for four days, the $\mathrm{pH}$ value of patin fish fillet decreased and increased on the next day. The decreasing of $\mathrm{pH}$ is one indicator of entering into rigor mortis phase. The change of rigor mortis in the fish resulted from a series of complex chemical change in the muscles of fish after its death [33]. This change decreases the $\mathrm{pH}$ of the fish body followed with muscle tissue that cannot maintain its elasticity. Fish temperature is the most important factor during rigor mortis process [34]. The lower the temperature, the slower the process of entering into rigor mortis phase, and the longer the rigor mortis phase. It occurs because there is an enzymatic reaction that will be spurred by its activity with the increased temperature.

After $\mathrm{pH}$ value has decreased in each treatment on the day- $4, \mathrm{pH}$ value of patin fish fillet increased on the day- 8 and further days. After 16 day storage at $4 \pm 1^{\circ} \mathrm{C}$, the highest $\mathrm{pH}$ value of 7.92 occurred in the activity of $0 \mathrm{IU} / \mathrm{ml}$, while the lowest one occurs in the nisin activity of $2000 \mathrm{IU} / \mathrm{ml}$. At the beginning of storage, the ANOVA test showed that there was no significant effect of nisin activity on $\mathrm{pH}$ values of patin fish fillet. However, on the day-4 up to day-12, the ANOVA test showed that nisin activity significantly affected the $\mathrm{pH}$ value of patin fish fillet. After four days storage, $\mathrm{pH}$ values of $0 \mathrm{IU} / \mathrm{ml}$ and $1000 \mathrm{IU} / \mathrm{ml}$ samples were significantly different from those of 500 $\mathrm{IU} / \mathrm{ml}$ and $2000 \mathrm{IU} / \mathrm{mL}$ samples. Meanwhile, on the day-8 and 12, $\mathrm{pH}$ value of $0 \mathrm{IU} / \mathrm{ml}$ sample was significantly higher than that of others treatment samples. 


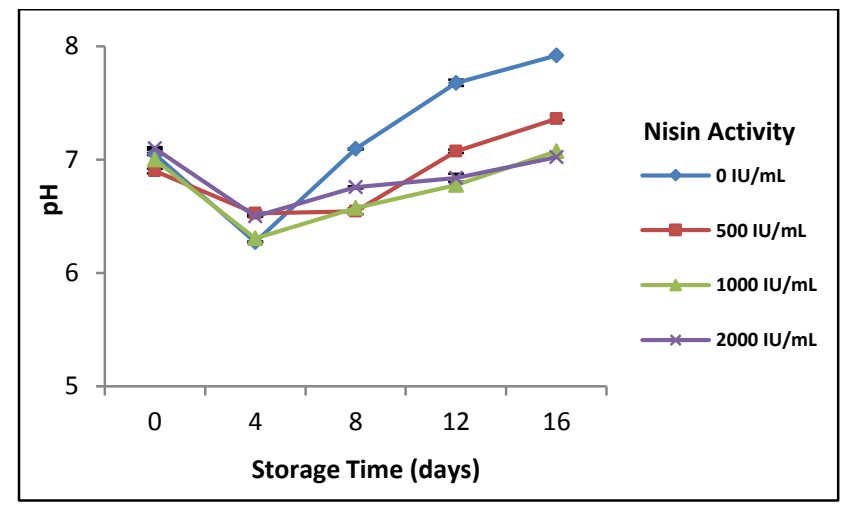

Figure 2 The Effect of Edible Coating Enriched with Nisin on $\mathrm{pH}$ Value of Patin Fish Fillet During Cold Storage at $4 \pm 1^{\circ} \mathrm{C}$

The increasing of $\mathrm{pH}$ value in fish fillet is due to the formation of base compound. During the storage process, nitrogen compound composition resulted in the increased $\mathrm{pH}$ value in fish meat likely related to the production of alkali compound [7]. In further decomposition process, $\mathrm{pH}$ of fish will increase because there are base compounds such as ammonia, trimethylamine, and other volatile compounds as the result of bacterial and proteolytic enzyme activities [35]. During storage process, protein in fish meat encountered proteolysis to be the amino acid. In the presence of microbe, amino acid will be utilized by the microbe in which this activity will result in base compounds.

Previous studies reported that the application of $15 \mu \mathrm{g} / \mathrm{ml}$ nisin in fish meatball did not show significantly different $\mathrm{pH}$ value compared with that in control fish [36]. Similarly, another study showed that $\mathrm{pH}$ value in trout rainbow fish, either control or experiment group with nisin of $100 \mu \mathrm{g} / \mathrm{g}$, shows insignificance difference despite lower $\mathrm{pH}$ value in the sample treated with nisin [7]. However, the lower $\mathrm{pH}$ value in fish fillet with activity $200 \mathrm{IU} / \mathrm{ml}$ can be associated with the decomposer bacteria inhibiting property and the decreased basic amine production due to the antibacterial activity of nisin.

\subsection{Total Volatile Base}

Total Volatile Base (TVB) is one method to determine the fish freshness level by measuring the total number of the volatile base compound. The threshold of TVB value for fish and fishery product is $35 \mathrm{mg} \mathrm{N} / 100 \mathrm{~g}$ [37]. The TVB value of patin fish fillet increases as the storage time increases (Figure 3). The TVB value of patin fish fillet on the day-0 ranges between $9.97 \mathrm{mg}$ $\mathrm{N} / 100 \mathrm{~g}-12.16 \mathrm{mg} \mathrm{N} / 100 \mathrm{~g}$ and after that there is an increase in TVB value up to the day-16. In fish fillet with activity treatment of 0,500 , and $1000 \mathrm{IU} / \mathrm{ml}$ can maintain the fish freshness up to the day -8 while in the activity of $2000 \mathrm{IU} / \mathrm{ml}$ can maintain fish freshness up to the day- 12 .

After 16 days of storage, nisin activity affected the TVB value of patin fish fillet. The higher the activity of nisin, the lower the TVB value of samples. The TVB valueof of $2000 \mathrm{IU} / \mathrm{ml}$ sample was significantly lower than that of 1000,500 , and $0 \mathrm{IU} / \mathrm{ml}$ samples. It indicated that the higher the nisin activity, the lower the TVB value of samples. The effectiveness of nisin as a preservative is dependent on the concentration of nisin [4]. The lowest TVB value of fish fillet with higher nisin activity can be associated with the antibacterial property of nisin that can inhibit the decomposition by bacteria so that protein decomposition process by bacteria can decrease. There is a correlation between the microbial number and TVB value of fish in which the higher the number of microbes, the higher the TVB value [37].

Patin fish contain high levels of protein and contain higher amino acids compared to protein in milk or beef [38]. The protein on patin fish reaching $68.8 \%$ [39]. The role of microbe in improving TVB value is enzymes contained in fish meat will undertake transformation process thereby increasing nitrogen content in fish meat, such as amine and amino acid compound [30]. The presence of microbe will increase enzyme content thereby increasing the nitrogen content in the fish meat, such as amine and amino acid compound [30]. The presence of microbe will increase the enzyme content so that further transformation of amine and amino acid into trimethyl amine, ammonia, amine, and aldehyde. Nisin shows antimicrobial activity as the bactericidal and bacteriostatic agent in nature [29]. The effectiveness of nisin in inhibiting bacteria is dependent on nisin concentration [4]. Therefore, the antimicrobial activity of nisin can contribute to inhibiting the increasing of the TVB value of patin fish fillet. The higher the nisin activity, the higher the inhibiting activity of nisin and the lower the total volatile base value.

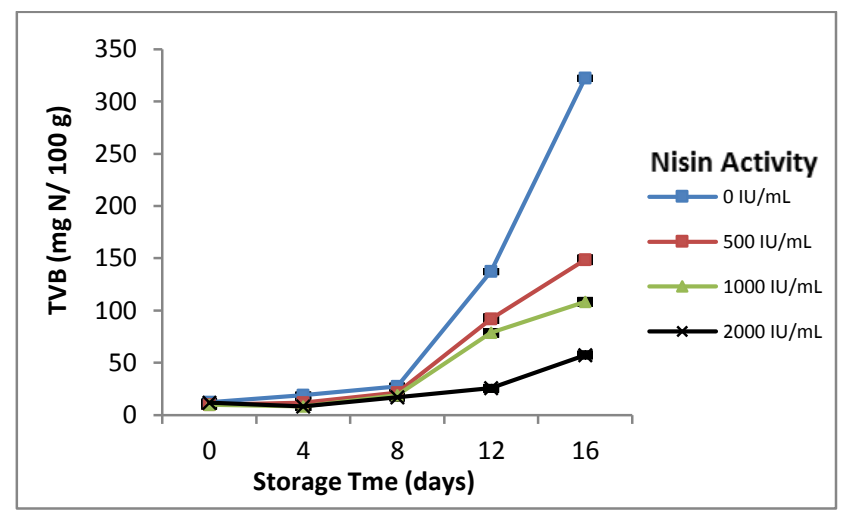

Figure 3 The Effect of Edible Coating Enriched with Nisin on TVB Value of Patin Fish Fillet During Cold Storage at $4 \pm 1^{\circ} \mathrm{C}$

\subsection{Thiobarbituric Acid}

The calculation of TBA value in patin fish fillet is conducted as the indicator of rancidity based on TBA (1-thiobarbituric acid) reaction with malonaldehyde. The standard reference of TBA value showing good quality in the fish product (frozen, cold, or stored with ice) is $5 \mathrm{mg}$ malonaldehyde (MA) per kilogram (mg $M A / \mathrm{kg}$ ) [40]. The initial TBA values of patin fish fillet 
ranged from $0.05-0.07 \mathrm{mg} \mathrm{MA} / \mathrm{kg}$. After 16 days of storage, the TBA values of $0 \mathrm{IU} / \mathrm{ml} ; 500 \mathrm{IU} / \mathrm{ml} ; 1000$ $\mathrm{IU} / \mathrm{ml}$ and $2000 \mathrm{IU} / \mathrm{ml}$ samples were $0.47 ; 0.16 ; 0.16$; and $0.12 \mathrm{mg} \mathrm{MA} / \mathrm{kg}$, respectively. Nisin activity significantly affected the TBA value of patin fish fillet.

The increasing of TBA value indicated that the oxidation reaction was occurring continuously in the fish fillet. Fat content in patin fish is relative low at around 5.8\% [39]. Fat oxidation in the fish can occur enzymatically and non-enzymatically. Fat enzymatic hydrolysis by lipase is usually called lipolysis (fat damage). In this process, lipase breaks glyceride and creates free fatty acids resulting in the loss of flavor, accelerating rancidity and decreasing its oil quality [41]. Meanwhile, non-enzymatic oxidative damage in fish occurs due to fat oxidation process by free air. Free oxygen oxidizes double bond in unsaturated fatty acid [42]. Then, free radicals and oxygen create active peroxide that can create hydroperoxide that is very unstable. This hydroperoxide can oxidize the intact or decomposed fatty acid resulting in aldehyde, ketone, alcohol, polymer, and etc with low molecular weight.

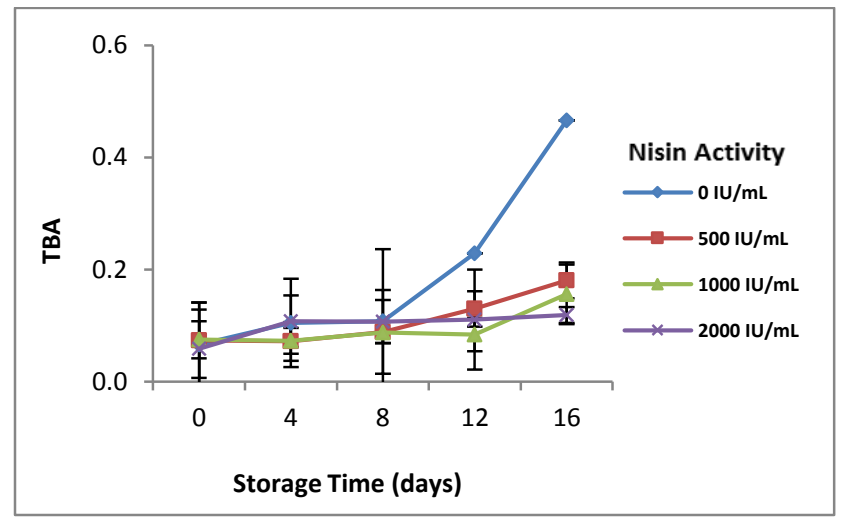

Figure 4 The Effect of Edible Coating Enriched with Nisin on TBA Value of Patin Fish Fillet During Cold Storage at $4 \pm 1^{\circ} \mathrm{C}$

Some studies show similar TBA value. The comparison between control trout rainbow fish and the one treated with nisin $100 \mu \mathrm{g} / \mathrm{g}$ show significantly lower TBA value in the fish treated with nisin and each of treatment is still below the threshold acceptable for human consumption [7]. In grass carp fish immersed into nisin solution $0.1 \%$ and $0.2 \%$, it can be found the significant difference of TBA value in which the immersion treatment $0.2 \%(0.30 \mathrm{mg} \mathrm{MA} / \mathrm{kg})$ shows lower TBA value than the nisin immersion treatment $0.1 \%(0.38 \mathrm{mg} \mathrm{MA} / \mathrm{kg}$ ) and control (0.46 mg MA/kg) [41]. This result is still fulfill the acceptable threshold of $7-8 \mathrm{mg} \mathrm{Ma} / \mathrm{kg}$ after having been stored at $4{ }^{\circ} \mathrm{C}$ for 16 days.

\subsection{CONCLUSION}

The application of nisin enriched on tapioca-based edible coating affected the TPC, TVB and TBA values but did not affect the $\mathrm{pH}$ value of patin fish fillet stored at cold temperature $\left(4 \pm 1^{\circ} \mathrm{C}\right)$. The higher nisin activity enriched on the tapioca-based edible coating solutions, the lower the TPC, TVB, and TBA values of patin fish fillet that indicating the better effect on maintaining the quality of patin fish fillets. Enrichment of nisin at $2000 \mathrm{lU} / \mathrm{ml}$ on tapioca-based edible coating solution could maintain the patin fish fillets quality during $16^{\text {th }}$ day stored at $4 \pm 1{ }^{\circ} \mathrm{C}$.

\section{References}

[1] Ministry of Marine Affairs and Fisheries. 2013. Kelautan dan Perikanan dalam Angka 2013 (Marine and Fisheries in Figures 2013). http://www.kkp.go.id. Accessed at 6 April 2015.

[2] Trade Ministry of Republic Indonesia. 2013. Ikan Patin Hasil Alam Bernilai Ekonomi dan Berpotensi Ekspor Tinggi. Warta Ekspor. Edisi Oktober 2013.

[3] Wibowo, S., and Yunizal. 1998. Penanganan Ikan Segar. Jakarta: Marine Fisheries Installation.

[4] Fawzya, Y. N. 2010. Bahan Pengawet Nisin: Aplikasinya pada Produk Perikanan. Squalen. 5(3): 79-85.

[5] National Agency of Drug and Food Control Republic Indonesia. 2013. Batas Maksimum Penggunaan Bahan Tambahan Pangan Pengawet Nomor 36. Jakarta: National Agency of Drug and Food Control Republic Indonesia.

[6] Cleveland, J., Thomas, J. M., Ingolf, F. N., and Michael, L. C. 2001. Bacteriocins: Safe, Natural Antimicrobials for Food Preservation. Int. J. Food Microbiology. 71: 1-20.

DOI: https://doi.org/10.1016/S0168-1605(01)00560-8.

[7] Behnam, S., Mohammad, A., Masoud, R., Siyavash, S., and Reza, S. 2015. Effect of Nisin as a Biopreservative Agent on Quality and Shelf Life of Vacuum Packaged Rainbow Trout (Oncorhynchus mykiss) Stored at $4^{\circ} \mathrm{C}$. Journal Food Science and Technology. 52(4): 2184-2192.

DOI: https://doi.org/10.1007/s13197-013-1241-2.

[8] Aldilla, S. N., Utami, R., Nursiwi, A., and Nurhartadi, E. 2017. The Effect of Nissin from Lactococcus latis subsp. lactis on Refrigerated Patin Fillet Quality. IOP Conf. Series: Material Science and Engineering. 193(2017): 1-6

DOI: https://doi.org /10.1088/1757-899X/193/1/012014.

[9] Resa, Carolina P. O., Lia, N., Gerschenson, and Rosa, J. J. 2014. Natamycin and Nisin Supported on Starch Edible Films for Controlling Mixed Culture Growth on Model Systems and Port Salut Cheese. Journal Food Control. 44: $146-151$.

DOI: https://doi.org/10.1016/j.foodcont.2014.03.054.

[10] Basch, Clara, Joaquin, C., Rosa J. J., and Silvia, F. 2011. Individual and Combined Performance of Nisin and Potassium Sorbate Supported in Tapioca Starch Edible Films. International Congress on Engineering and Food (ICEF 11). 2: 979-980.

[11] Coma, V., Sebti, I., Pardon, P., Deschamps, A., Pichavant, F. H. 2001. Antimicrobial Edible Packaging Based on Cellulosic Ethers, Fatty Acids, and Nisin Incorporation to Inhibit Listeria innocua and Staphylococcus aureus. J. Food Prot. 64: 470e475. DOI: https://doi.org/10.4315/0362-028X-64.4.470.

[12] Gadang, V. P., Hettiarachchy, N. S., Johnson, M. G., and Owens, C. 2008. Evaluation of Antibacterial Activity of Whey Protein Isolate Coating Incorporated with Nisin, Grape Seed Extract, Malic Acid, and EDTA on a Turkey Frankfurter System. J. Food Sci. 73: M389eM394. DOI: https://doi.org /10.1111/j.1750-3841.2008.00899.x.

[13] Ko, S., Janes, M. E., Hettiarachchy, N. S., and Johnson, M. G. 2001. Physical and Chemical Properties of Edible Films Containing Nisin and Their Action Against Listeria Monocytogenes. J. Food Sci. 66: 1006e1011. 
[14] Kristo, E., Koutsoumanis, K. P., and Biliaderis, C. G. 2008. Thermal, Mechanical and Water Vapor Barrier Properties of Sodium Caseinate Films Containing Antimicrobials and Their Inhibitory Action on Listeria Monocytogenes. Food Hydrocol. 22: 373e386.

DOI: https://doi.org /10.1016/j.foodhyd.2006.12.003

[15] Natrajan, N., and Sheldon, B. W. 2000. Inhibition of Salmonella on Poultry Skin Using Protein- and Polysaccharide-based Films Containing a Nisin Formulation. J. Food Prot. 63: 1268e 1272.

[16] Nguyen, V. T., Gidley, M. J., and Dykes, G. A. 2008. Potential of a Nisin-containing Bacterial Cellulose Film to Inhibit Listeria Monocytogenes on Processed Meats. Food Microbiol. 25: 471e478.

DOI: https://doi.org /10.1016/j.fm.2008.01.004.

[17] Sanjurjo, K., Flores, S., Gerschenson, L., and Jagus, R. 2006. Study of the Performance of Nisin Supported in Edible Films. Food Res. Int. 39: 749e754.

DOI: https://doi.org/10.1016/j.foodres.2006.01.016.

[18] Cao-Hoang, L., Chaine, A., Gregoire, L., and Wache, Y. 2010. Potential of Nisin-incorporated Sodium Caseinate Films to Control Listeria in Artificially Contaminated Cheese. Food Microbiol. 27(7): 940-944. DOI: https://doi.org/10.1016/j.fm.2010.05.025.

[19] Utami, R., Kawiij, Nurhartadi, E., Kurniasih, M., and Indianto, D. 2013. Effect of Edible Coating Enriched with Red Ginger and Red Galangal Essential Oil on the Quality of Patin Fillet. Agritech. 33(4): 399-406. DOI: https://doi.org/10.22146/agritech.9535.

[20] Utami, R., Kawiji, Nurhartadi, E., Putra, A. Y. T., and Setiawan, A. 2014. The Effect of Cassava Starch-based Edible Coating Enriched with Kaempferia Rotunda and Curcuma Xanthorrhiza Essential Oil on Refrigerated Patin Fillets Quality. International Food Research Journal. 21(1): 413-419.

[21] Utami, R., Kawiji, Praseptiangga, D., Manuhara, G. J., Khasanah, L. U., Anggraini, N., and Lestari, F. M. 2016. Short Communication: Preservation Effect of Javanese Turmeric and Red Ginger Essential Oils on Coated Frozen Patin Fillets. Nusantara Bioscience. 8(2): 264-267. DOI: https://doi.org/10.13057/nusbiosci/n080220.

[22] Utami, R., Praseptiangga, D., Nurhartadi, E., Manuhara, G. J., Khasanah, L. U., Azzahra, F. A., and Indrayati, F. 2016. Cassava Starch-based Edible Coatings Enriched with Alpinia purpurata and Kaempferia rotunda Essential Oils for Patin Fillets Preservation. Jurnal Teknologi. 78(4-2): 193-198.

[23] Millette, M., Le Tien, C., Smoragiewicz, W., and Monique, L. 2007. Inhibition of Staphylococcus aureus on Beef By NisinContaining Modified Alginate Films and Beads. Journal Food Control. 18: 878-884.

DOI: https://doi.org/10.1016/j.foodcont.2006.05.003.

[24] Standardization National Agency. 2015. Cara Uji Mikrobiologi - Bagian 3: Penentuan Angka Lempeng Total (ALT) pada Produk Perikanan. SNI 2332.3:2015. Jakarta: Standardization National Agency.

[25] Association of Official Analytical Chemist (AOAC). 1995. Official Methods of Analysis. 14 th Edition. Washington DC.

[26] Standardization National Agency. 2009. Cara Uji Kimia Bagian 8: Penentuan Kadar Total Volatile Base Nitrogen (TVB-N) dan Trimetil Amin Nitrogen (TMA-N) pada Produk Perikanan. SNI 2354.8:2009. Jakarta: Standardization National Agency.

[27] Apriyantono, Anton, Dedi Fardiaz, Ni Luh Puspitasari, Sedarnawati, dan Slamet Budiyanto. 1989. Petunjuk Laboratorium Analisis Pangan. IPB-Press. Bogor.
[28] Standardization National Agency. 2009. Batas Maksimum Cemaran Mikroba dalam Pangan. SNI 7889:2009. Jakarta: Standardization National Agency.

[29] Usmiati, Sri and Richana Nur. 2011. Potensi Bakteriosin dari Lactobacilus sp. Galur SCG 1223 sebagai Biopreservatif pada Daging Segar. Buletin Teknologi Pascapanen Pertanian. 7(2): 66-77.

[30] Liviawaty, Evi, and Eddy Afrianto. 2010. Penanganan Ikan Segar. Bandung: Widya Pandjadjaran.

[31] Noseda, B., Tariqul, I., Markus, E., Marc, H., Koen De R. Herman, V. L., and Frank, D. 2012. Microbiological Spoilage of Vacuum and Modified Atmosphere Packaged Vietnamese Pangasius hypophthalmus Fillets. Food Microbiology. 30: 408-419.

DOI: https://doi.org/10.1016/j.fm.201 1.12.025.

[32] Rahimabadi, E., Zakipour, Rigi, M., and Rahnama, M. 2013. Combined Effects of Zataria Multiflora Boiss Essential Oil and Nisin on the Shelf-life of Refrigerated Rainbow Trout (Onchorynchus mykiss) Fillets. Iranian Journal of Fisheris Sciences. 12(1): 115-126.

[33] Baladin, La Ode. 2007. Studi Ketahanan Hidup Larva Anisakidae dengan Suhu Pembekuan dan Penggaraman pada Ikan Kembung (Rastrelliger spp.). Bogor: Pascasarjana Istitut Pertanian Bogor.

[34] Bahar, Burnam. Paduan Praktis Memilih dan Menangani Produk Perikanan. 2006. Jakarta: Gramedia Pustaka Utama.

[35] Cassens, R. G. 1994. Meat Preservation, Preventing Losses and Assuring Safety, $1^{\text {st }}$ Edition. USA: Food and Nutrition Press, Inc. Trumbull, Connecticut.

[36] Vongsawasdi, Punchira, Monthira Nopharatana, Pattarim Supanivatin, dan Matthana Promchana. 2012. Effect of Nisin on the Survival of Staphylococcus aureus Inoculated in Fish Balls. Asian Journal of Food and Agro-Industry. 5(01): 52-60.

[37] Ozyurt, Gulsun, Esmeray Kuley, Serhat Ozkutuk, and Fatih Ozogul. 2009. Sensory, Microbiological and Chemical Assessment of the Freshness of Red Mullet (Mullus Barbatus) and Goldband Goatfish (Upeneus Moluccensis) During Storage in Ice. Journal Food Chemistry. 114: 506-610. DOI: https://doi.org/10.1016/j.foodchem.2008.09.078.

[38] Suryaningrum, Th. D., Muljanah, I., and Suryanti. 2012. Membuat Filet Ikan Patin. Penebar Swadaya. Jakarta.

[39] Khairuman, and Sudenda, D. 2002. Budidaya Ikan Patin Secara Intensif. Depok. Agro Media Pustaka.

[40] Sallam, K. I. 2007. Antimicobial and Antioxidant Effects of Sodium Acetat, Sodium Lactate, and Sodium Citrate in Refrigerated Sliced Salmon. Journal Food Control. 18(5): 566-575. DOI: https://doi.org/10.1016/j.foodcont.2006.02.002.

[41] Puspitasari and Sari, A. P. 2012. Pengawetan Suhu Rendah Pada Ikan dan Daging. Fakultas Kedokteran. Semarang: Universitas Diponegoro.

[42] Ketaren, S. 1986. Pengantar Teknologi Minyak dan Lemak Pangan. Jakarta: Universitas Indonesia- Press.

[43] Langroudi, Hamid, F., Mehdi, S., Abolghasem, K., Mohammad, R. G., Seyed, E. H., Soottawat, B., and Zoheir, H. 2011. Effect Of Listeria Monocytogenes inoculation, Sodium Acetate And Nisin On Microbiological And Chemical Quality Of Grass Carp during Refrigeration Storage. African Journal of Biotechnology. 10(42): 84848490.

DOI: https://doi.org/10.5897/AJB1 1.688. 